\title{
Bile acids and their role in functional gastrointestinal disorders
}

\section{Kwasy żółciowe i ich rola w zaburzeniach czynnościowych przewodu pokarmowego}

\author{
Radosław Andrzej Konieczny ${ }^{1, B-D}$, Wojciech Różański ${ }^{1, B, C}$, Elżbieta Poniewierka ${ }^{2, A, E, F}$, \\ Radosław Kempiński2, ${ }^{2, E, F}$, Katarzyna Neubauer, ${ }^{3, F}$, \\ ${ }^{1}$ Clinic of Gastroenterology and Hepatology, Jan Mikulicz-Radecki University Teaching Hospital, Wrocław, Poland \\ 2 Department and Clinic of Gastroenterology and Hepatology, Wroclaw Medical University, Wrocław, Poland \\ ${ }^{3}$ Division of Dietetics, Department and Clinic of Gastroenterology and Hepatology, Wroclaw Medical University, Wrocław, Poland \\ A - research concept and design; $\mathrm{B}$ - collection and/or assembly of data; $\mathrm{C}$ - data analysis and interpretation; \\ $D$ - writing the article; $E$ - critical revision of the article; $F$ - final approval of the article
}

Address for correspondence

Radosław Andrzej Konieczny

E-mail: rkonieczny.med@gmail.com

Funding sources

None declared

Conflict of interest

None declared

Received on October 31, 2018

Reviewed on December 11, 2018

Accepted on December 30, 2018

\begin{abstract}
Studies of the role of bile acids have been conducted for many years. Thanks to constantly improving research methods, the systemic action of bile acids has been evaluated with increasing precision. It is now believed that disturbances in the synthesis, transformation and transport of bile acids may be one of the causes of functional bowel disorders. Constant renewal of the bile acid pool and secretion of bile acids into the gastrointestinal lumen is regulated by feedback loops. Bile acids play the role of signaling molecules by binding to the appropriate receptors and influencing the synthesis of other signaling molecules at the cellular level. Disturbances of synthesis, reabsorption and changes in the proportion of bile acids all lead to motor dysfunction and intestinal secretion. The most common symptoms are diarrhea, constipation or irritable bowel syndrome. This article discusses the basic issues of the synthesis and circulation of bile acids. On the basis of in vitro and in vivo findings, an outline of the regulation of physiological processes and the pathophysiology of diarhea and constipation in the context of bile acids is presented. Understanding the role of bile acids in the pathophysiology of functional intestinal diseases creates new therapeutic options for patients suffering from functional diarrhea or constipation.
\end{abstract}

Key words: bile acids, constipation, peristalsis, diarrhea

Cite as

Konieczny RA, Różański W, Poniewierka E, Kempiński R, Neubauer K. Bile acids and their role in functional gastrointestinal disorders. Piel Zdr Publ. 2019;9(2):107-112. doi:10.17219/pzp/102439

DOI

$10.17219 / \mathrm{pzp} / 102439$

Copyright

○ 2019 by Wroclaw Medical University

This is an article distributed under the terms of the

Creative Commons Attribution Non-Commercial License

(http://creativecommons.org/licenses/by-nc-nd/4.0/) 


\section{Streszczenie}

Badania dotyczące roli kwasów żókciowych są prowadzone od wielu lat. Dzięki stale udoskonalanym metodom badawczym udaje się coraz precyzyjniej oceniać działanie systemowe kwasów żółciowych. Obecnie uważa się, że zaburzenia syntezy, przemian i transportu kwasów żółciowych mogą być jedną z przyczyn czynnościowych zaburzeń jelit. Stałe odnawianie puli kwasów żółciowych oraz ich sekrecja do światła przewodu pokarmowego podlegają regulacji na zasadzie sprzężeń zwrotnych. Kwasy żółciowe pełnią rolę cząsteczek sygnałowych, wiążąc się z odpowiednimi receptorami i wpływając na syntezę innych cząsteczek sygnałowych na poziomie komórkowym. Zarówno zaburzenia syntezy, reabsorpcji, jaki i zmiany proporcji kwasów żółciowych prowadzą do zaburzeń motoryki oraz sekrecji jelitowej. Najczęstszymi objawami są biegunka, zaparcie lub zespół jelita nadwrażliwego. Wartykule omówiono podstawowe zagadnienia dotyczące syntezy oraz krążenia kwasów żółciowych. Na podstawie wniosków z badan in vitro oraz in vivo przedstawiono zarys regulacji procesów fizjologicznych oraz patofizjologię możliwych przyczyn biegunki i zaparć w kontekście działania kwasów żókciowych. Poznanie roli kwasów żókciowych w patofizjologii czynnościowych chorób jelit stwarza nowe możliwości terapeutyczne dla chorych na biegunkę i zaparcia czynnościowe.

Słowa kluczowe: kwasy żółciowe, zaparcie, biegunka, perystaltyka

Studies of the role of bile acids have been conducted for many years. Initially, interest was aroused by their participation in the development of cholelithiasis. Thanks to constantly improving research methods, the systemic action of bile acids has been evaluated with increasing precision. It is believed that disturbances in the synthesis, transformation and transport of bile acids may cause functional bowel disorders.

Bile acids are amphipathic molecules. In water, their anionic forms combine to form micelles, which help in the digestion and absorption of fats. In addition, bile acids are also signaling molecules that interact with specific receptors to regulate important biological processes. The main role of bile acids is emulsification, thus facilitating the digestion and absorption of fats in the intestine.

Bile acids are synthesized from cholesterol in liver cells. There are 2 multi-step pathways of bile acid synthesis. The main pathway, responsible for $95 \%$ of this synthesis, includes microsomal cholesterol 7a-hydroxylase (CYP7A1). The secondary pathway includes mitochondrial sterol 27-hydroxylase (CYP27A1). ${ }^{1}$

Newly synthesized bile acids are conjugated with taurine and glycine, which makes them more water-soluble. Conjugated bile acids are transported into the bile by the bile salt export pump (BSEP) and multidrug-resistance protein 2 (MRP2), and are stored in the gallbladder. ${ }^{2}$ When food enters the duodenum, cholecystokinin causes contractions of the gallbladder and bile is excreted into the duodenum. After fulfilling their function in the lumen of the gastrointestinal tract, about 95\% of bile acids are reabsorbed in the small intestine. The sodium-dependent bile acid transporter (ASBT), also known as the ileal bile acid transporter (IBAT), uptakes bile acids from the apical membranes of the enterocytes into the cells. Inside the enterocytes, bile acids are bound to the ileal bile acid binding protein (IBABP). After that, the organic solute transporter alpha/beta (Ost $\alpha / \beta)$ transports the bile acids into portal circulation through the basal membranes of the enterocytes. This system of proteins is crucial to maintain homeostasis of enterohepatic circulation. ${ }^{3}$
Bile acids that are not absorbed in the small intestine are partially dehydroxylated and deconjugated from the taurine and glycine groups to form secondary bile acids. Secondary bile acids are reabsorbed only by passive transport (diffusion) from the large intestine or excreted with a stool. Passive absorption (another means of diffusion) depends on the $\mathrm{pH}$ and on the extent to which bile acids have been biologically processed by the bacterial flora of the colon. ${ }^{4}$ In healthy people, the enterohepatic circulation of the bile acid pool takes place in 6-10 cycles per day, and the pool of bile acids is about $2.7 \mathrm{~g}$ (median $25-75$ percentile of $2.5-3.1 \mathrm{~g}) .^{5}$

\section{Regulation of bile acid synthesis}

Due to the loss of bile acids with stool, their constant synthesis is needed to renew the pool. This process is regulated on the basis of feedback loops. The best-characterized receptor involved in this process is the farnesoid $\mathrm{X}$ receptor (FXR). The highest expression of FXR encoding mRNA occurs in the ileum; its expression is lower in the liver and large intestine. ${ }^{6}$

Bile acids bind to the FXR receptor and increase the synthesis of fibroblast growth factor 19 (FGF-19). It is a signal molecule produced by ileum cells and is released into the venous (portal) blood. A specific fraction of receptors - FGF19-R - is found in hepatocytes. When combined with the FGF-19, a cascade of intracellular signals is triggered in hepacytes, leading to the suppression of CYP7A1 expression and, as a consequence, suppression of bile acid synthesis.?

\section{Methods for determining bile acids in vivo}

Various methods using different measurements have been created to study the enterohepatic circulation of bile acids. In addition to determining the amount of bile acids in the stool, which is troublesome because it requires 2 
to 3 days of stool collection, there are a number of methods to assess malabsorption of bile acids.

A test based on determining 23-seleno-25-homotaurocholic acid (SeHCAT) - homotaurocholic acid labeled with selenium 75 - is considered the gold standard in the diagnosis of bile acid malabsorption in several European countries; however, in Poland this is not a routine test. The test starts with the administration of a radioactive label in the form of an oral capsule. The SeHCAT molecule facilitates accurate assessment of the active absorption of bile acids because it does not undergo passive penetration through the intestine wall and resists bacterial deconjugation. ${ }^{8}$ The test entails measuring radiation after $3 \mathrm{~h}$, which is treated as point 0 . The next measurement is carried out after 7 days. Label retention below $10 \%$ is considered pathological; it indicates a high loss of bile acids with stool and insufficient active absorption of bile acids.

To assess the current synthesis of bile acids, the concentration of intermediate substances from the synthesis pathway is determined. The intermediate molecule most frequently used in this test is 7-alpha-hydroxy-4-cholesten-3-one (C4). Its concentration can be measured in peripheral blood and reflects the current synthesis of bile acids.

Studies of C4 concentration have shown increased synthesis of bile acids in patients after ileal resection, in patients with Crohn's disease and in patients with irritable bowel syndrome with diarrhea (IBS-D). The values noted were significantly higher than in healthy volunteers. ${ }^{9}$

Studies are still being carried out in search of the optimal bile acid malabsorption biomarker for clinical use. Such an indicator could be, for example, the concentration of FGF-19 alone or in combination with other parameters. One study reported on the utility of fluorine (19F)-labeled bile acid analogs and magnetic resonance imaging (MRI) in identifying altered bile acid transport in mice. ${ }^{10}$ Two groups of mice were compared: wild-type and FGF15-deficient mice (FGF15 is a murine homo$\log$ of human FGF-19). After dosing the animals orally, the researchers quantified 19F-labeled bile acid analog levels in the gallbladder, liver, intestine, and plasma using liquid chromatography. The signal of the 19F-labeled bile acid analogs measured in the gallbladders of the FGF15deficient mice was several times less intensive than in the gallbladders of the wild-type mice. The authors of that study suggested that 19F-labeled bile acid analogs combined with MRI are a potential tool for diagnosing bile acid diarrhea due to FGF-19 deficiency.

\section{Disorders of bile acid absorption}

Several studies have found that diarrhea after ileal resection results from bile acid absorption disturbance or biliary acid malabsorption (BAM). There are 3 types of disturbances of bile acid absorption ${ }^{11}$ : BAM Type 1 , associated with structural damage of the ileum caused by the inflammatory process, post-radiation changes or following intestinal resection; BAM Type 2, which is idiopathic, including situations in which absorption disorders can be determined using reliable tests, but the etiology is not known; and BAM Type 3, which is secondary to other diseases.

\section{Changes in the proportions of bile acids}

In addition to quantitative changes, deviations in the proportions of bile acids are also important. They can be the cause or the effect of certain diseases. For example, in patients with diarrhea or altered intestinal flora, the amount of chenodeoxycholic acid (CDCA) may be equal to the amount of deoxycholic acid. ${ }^{12}$ In patients with Crohn's disease, due to impaired bile acid absorption, higher concentrations of primary (cholic and chenodeoxycholic) acids and reduced concentrations of secondary acids were found in bile from the gallbladder as compared to cholecystectomy patients. ${ }^{4}$ In patients with BAM Type 1, the composition of bile acids is also altered, with an increased proportion of primary acids. In BAM Types 2 and 3 , the data are limited and thus not indicative.

\section{The influence of bile acids on intestinal mucosal secretion}

It is known that bile acids have a significant effect on the secretory functions of the large intestine. In the cecum, the concentration of bile acids is about $0.6 \mathrm{mM}$. Water secretion begins in the colon when the concentration of bile acids reaches $3-10 \mathrm{mM}$. However, this does not apply to all bile acids to the same extent: cholic acid does not induce secretion, while CDCA induces secretion at $5 \mathrm{mM}$ and deoxycholic at $3 \mathrm{mM} \cdot{ }^{13}$ It is worth mentioning that such high concentrations of bile acids only occur only after large resections of the small intestine. ${ }^{14}$

Bile acids induce intestinal secretion by activating intracellular mechanisms (increasing the concentration of cyclic adenosine-3',5'-monophosphate (CAMP)), ${ }^{15}$ by the detergent effect ${ }^{16}$ or by increasing cell membrane permeability and inhibiting the $\mathrm{Cl}^{-} / \mathrm{OH}^{-}$exchanger. ${ }^{17}$ The G-protein-coupled bile acid receptor (TGR5) is found in the submucosal ganglia of the large intestine. When combined with bile acid, the TGR5 receptor triggers a cascade of signals, causing increase in intracellular CAMP concentration. ${ }^{18}$ Various bile acids have different affinities for the TGR5 receptor.

Intestinal flora is another factor regulating the activity of bile acids. Anaerobic colon flora produces 15-20 different bile acid metabolites. ${ }^{19}$ Cholic acid, which does not affect intestinal secretion, is processed by bacteria into 
deoxycholic acid, which intensifies intestinal secretion. In turn, CDCA, which is induces secretion, is processed into lithocholic acid, which does not induce intestinal secretion. ${ }^{13}$

In addition to targeting specific receptors, it has been shown that bile acids can have a direct effect on the cholinergic system. Taurocholic acid acts as a partial cholinergic agonist. ${ }^{20}$ The physiological role of bile acid interaction with cholinergic muscarinic receptors is debatable, although it is known that bile acids at millimolar concentrations activate muscarinic receptors. The full significance of this, however, has yet to be determined.

\section{The influence of bile acids on intestinal motor functions}

Functional disorders induced by bile acids, especially diarrhea, are usually attributed to their secretion. It should be noted that bile acids influence intestinal peristalsis by acting on the smooth muscles regardless of the effects of secretion. The first in vivo studies in animals showed that the administration of primary (tauro- and glycocholic) bile acids to the cecum or intrarectally induces sigmoidal spasticity. ${ }^{21}$ Interestingly, the administration of these acids to the cecum simultaneously induces sigmoid spasms. In subsequent studies, the myoelectric activity of the proximal sigmoid colon after the administration of deoxycholic acid was measured using specially designed electrodes. No changes in the slow base rhythm were observed, while electric waves along the intestine were observed, causing intestinal muscle spasms. ${ }^{22}$

In human studies, administering deoxycholic acid up to $1 \mathrm{mmol} / \mathrm{L}$ reduces the rectal volume required for an urge to defecate. At a concentration of $3 \mathrm{mmol} / \mathrm{L}$, most subjects experienced an urgent need for defecation within 2-30 min after bile acid administration. Other intestinal spasms that are not observed when administering saline solution also appeared. ${ }^{23}$ Similar results were obtained by administering CDCA. ${ }^{24}$ At the conclusion of the study, it was found that CDCA in physiological concentrations might induce peristaltic movements originating in the proximal colon.

In another study, oral administration of CDCA gastro-resistant capsules reduced intestinal transit time, decreased stool density and increased the rate of defecation. ${ }^{25}$ Intramural intestinal neurons are probably involved in the transmission of this stimulus; however, there has only been 1 study of this phenomenon and its results indirectly suggest from the observation that this response may be inhibited by administering anesthetics (tetrodotoxin and procaine) to the intestinal lumen in the animal model. ${ }^{26}$

\section{Bile acids and diarrhea}

According to one study, ${ }^{27}$ bile acid absorption disorders occur in $30 \%$ of subjects with diarrhea of undetermined etiology. There have been many experimental studies documenting the stimulating effect of bile acids on intestinal peristalsis. However, only few of them were aimed at assessing changes in the functioning of the intestinal muscles in relation to the concentration of bile acids in the stool or in the colon. A study of 12 subjects reported a significant association between bile acid secretion and colonic peristalsis in response to food and prostagmin (an anticholinesterase agent). ${ }^{21}$

In another study, 43 patients with chronic diarrhea and diagnosed malabsorption of bile acids were evaluated using the SeHCAT test. There was a significant reduction in intestinal transit time compared to healthy volunteers. Interestingly, the acceleration of the passage occurred only in the distal part of the colon. ${ }^{28}$

In summary, increases in intestinal secretion and changes in the proportion of bile acids in the stool are characteristic of BAM. The symptom is diarrhea or IBS-D, ${ }^{29}$ which is associated with increased secretion of water and mucus into the intestine, increased peristalsis and permeability of the mucous membrane. ${ }^{30}$

\section{Bile acids and constipation}

Only few studies have been devoted to the role of bile acids in the pathophysiology of constipation. A study by Vijayvargiya et al. ${ }^{31}$ at the Mayo Clinic (Rochester, USA) proposed that there is a group of patients with irritable bowel syndrome with constipation (IBS-C) in whom the amount of bile acids in the stool is reduced, which is either the reason for this disease, or there is another association with constipation in these people. The premise for that research was the fact that the administration of bile acid sequestrants, such as cholestyramine and colesevelam, used in the treatment of hypercholesterolemia, is known to cause constipation. This allowed the assumption that a deficiency of conjugated bile acids in the stool leads to constipation. Vijayvargiya et al. conducted their study on a small group and showed that 15\% of the subjects with IBS-C had bile acid concentrations below the $10^{\text {th }}$ percentile. However, it should be noted that in the control group the same disorder occurred in $9 \%$ of the subjects. In the end it was concluded that among patients with IBS-C there is a group of patients with reduced amounts of bile acids in the stool; however, it is a relatively small group. Thus, further research is required on a larger population of patients.

In previous studies, the Mayo group confirmed that bile acid concentrations in stool were higher in IBS-D patients than in IBS-C patients. A significant number of these patients had elevated serum C4 and decreased FGF-19, 
which is consistent with what is known about the regulation of bile acid synthesis through negative conjugation.

Another study at the Mayo Clinic also showed that the stool content of unconjugated bile acids (deoxycholic and chenodeoxycholic acid) was lower in patients with IBS-C, and lithocholic acid was higher in the same group, but this was not related to intestinal transit time. ${ }^{32}$

Deoxycholic acid increases the secretion of water into the lumen of the intestine, while the administration of CDCA intensifies peristaltic contractions of the large intestine. ${ }^{33}$ A shortage of these substances in theory can lead to increased stool density and less frequent bowel movements. In patients with constipation, a shortage of these bile acids may result from low synthesis caused by disturbances in the FGF-19 feedback loop and/or increased absorption of passive bile acids in the large intestine.

Another interesting report described a paradoxical $\mathrm{C} 4$ increase in the serum of patients with constipation, and slow passage compared to functional constipation. This suggests a compensatory increase in bile acid synthesis to provide an endogenous laxative factor. ${ }^{34}$ Other studies have assessed how intestinal passage affects the absorption and re-secretion of bile acids. Healthy volunteers, after the administration of loperamide (an agent used to decrease the frequency of diarrhea), had an increased concentration of deoxycholic acid in the bile. ${ }^{35}$ Conversely, patients with constipation, after the administration of sennosides, showed decreases in the concentration of deoxycholic acid in the bile. ${ }^{36}$ This confirms the existence of functional feedback loops regulating the intestinal passage and secretion of bile acids into the intestinal lumen. This regulation takes place both at the cellular and systemic levels.

Slow intestinal passage may also lead to more efficient conversion of bile acids by the bacterial flora of the colon by coupling with sulfate residues, which neutralizes bile acid secretory activity. In a study of children with constipation, it was shown that CDCA appeared in its inactive (sulfated) form. ${ }^{37}$ This may be due to slow intestinal transit and longer exposure of the acids to the intestinal flora. At the same time, bile acids, which are inactive in their secondary form, weaken the intestinal passage. It is difficult to indicate what constitutes the cause and what is the effect.

The treatment of patients with constipation due to a deficiency of bile acids could consist of agents increasing the excretion of bile acids. Indeed, the administration of CDCA in healthy people as well as in patients with IBS-C accelerated intestinal transit and increased the frequency of bowel movements. ${ }^{25,33}$ Another therapeutic approach would be to block IBAT to reduce the absorption of bile acids and increase their levels in the stool. The drug elobixibat, currently undergoing clinical trials, inhibits IBAT in the terminal ileum. ${ }^{38}$ By inhibiting the reabsorption of bile acids, elobixibat increases the amount of bile acids reaching the large intestine, which at the same time increases colonic motility and secretion. ${ }^{39}$ In a phase 2 randomized trial, a daily $10 \mathrm{mg}$ dose of elobixibat significantly increased the frequency of bowel movements and decreased stool density in patients with chronic constipation. ${ }^{39}$ There was also a decrease in low-density lipoprotein (LDL) cholesterol without affecting high-density lipoprotein (HDL) cholesterol, which is consistent with other studies on elobixibat. ${ }^{40}$

\section{Summary}

Modern research methods have allowed us to discover the molecular basis of action of bile acids on the digestive tract. Their quantity, qualitative composition and biological processing by the intestinal flora translate into the secretion and motor functions of the intestines. Knowledge of these factors provides a promising range of therapeutic options, which are at present undergoing clinical trials.

\section{ORCID iDs}

Radosław Andrzej Konieczny (1) https://orcid.org/0000-0002-0949-4364 Wojciech Różański (D) https://orcid.org/0000-0001-6358-4654

Elżbieta Poniewierka (D) https://orcid.org/0000-0002-2074-976X

Radosław Kempiński (D) https://orcid.org/0000-0002-6030-2700

Katarzyna Neubauer (D) https://orcid.org/0000-0003-3650-9311

\section{References}

1. Russell DW. The enzymes, regulation, and genetics of bile acid synthesis. Annu Rev Biochem. 2003;72:137-174. doi:10.1146/annurev biochem.72.121801.161712

2. Cheng S, Zou M, Liu Q, et al. Activation of 388 constitutive androstane receptor prevents cholesterol gallstone formation. Am J Pathol. 2017;187(4):808-818. doi:10.1016/j.ajpath.2016.12.013

3. Gonzalez FJ. Nuclear receptor control of enterohepatic circulation. Compr Physiol. 2012;2(4):2811-2828. doi:10.1002/cphy.c120007

4. Lapidus A, Åkerlund JE, Einarsson C. Gallbladder bile composition in patients with Crohn's disease. World J Gastroenterol. 2006;12(1): 70-74. doi:10.3748/wjg.v12.i1.70

5. Duane WC, Adler RD, Bennion LJ, Ginsberg RL. Determination of bile acid pool size in man: A simplified method with advantages of increases precision, shortened analysis time, and decreased isotope exposure. J Lipid Res. 1975;16(2):155-158.

6. Inagaki T, Moschetta A, Lee YK, et al. Regulation of antibacterial defense in the small intestine by the nuclear bile acid receptor. Proc Natl Acad Sci U S A. 2006;103(10):3920-3925. doi:10.1073 /pnas.0509592103

7. Jones S. Mini-review: Endocrine actions of fibroblast growth factor 19. Mol Pharm. 2008;5(1):42-48. doi:10.1021/mp700105z

8. Farkkila MA, Kairemo KJ, Taavitsainen MJ, Strandberg TA, Miettinen TA. Plasma lathosterol as a screening test for bile acid malabsorption due to ileal resection: Correlation with 75SeHCAT test and faecal bile acid excretion. Clin Sci (Lond). 1996;90(4):315-319.

9. Camilleri M, Nadeau A, Tremaine WJ, et al. Measurement of serum 7alpha-hydroxy-4-cholesten-3-one (or 7alphaC4), a surrogate test for bile acid malabsorption in health, ileal disease and irritable bowel syndrome using liquid chromatography-tandem mass spectrometry. Neurogastroenterol Motil. 2009;21(7):e734-743. doi: 10.1111/j.1365-2982.2009.01288.x

10. Metry M, Felton J, Cheng K, et al. Attenuated accumulation of novel fluorine (19F)-labeled bile acid analogues in gallbladders of fibroblast growth factor-15 (FGF15)-deficient mice. Mol Pharm. 2018; 15(11):4827-4834. doi:10.1021/acs.molpharmaceut.8b00454 
11. Bajor A, Gillberg PG, Abrahamsson H. Bile acids: Short and long term effects in the intestine. Scand J Gastroenterol. 2010;45(6):645-664. doi:10.3109/00365521003702734

12. Setchell KD, Lawson AM, Tanida N, Sjovall J. General methods for the analysis of metabolic profiles of bile acids and related compounds in feces. J Lipid Res. 1983;24(8):1085-1100.

13. Keely SJ, Scharl MM, Bertelsen LS, Hagey LR, Barrett KE, Hofmann AF. Bile acid-induced secretion in polarized monolayers of T84 colonic epithelial cells: Structure-activity relationships. Am J Physiol Gastrointest Liver Physiol. 2007;292(1):G290-297. doi:10.1152/ajpgi.00076.2006

14. Aldini R, Roda A, Festi $D$, et al. Bile acid malabsorption and bile acid diarrhea in intestinal resection. Dig Dis Sci. 1982;27(6):495-502.

15. Conley DR, Coyne MJ, Bonorris GG, Chung A, Schoenfield LJ. Bile acid stimulation of colonic adenylate cyclase and secretion in the rabbit. Am J Dig Dis. 1976;21(6):453-458. doi:10.1007/BF01072128

16. Camilleri M, Murphy R, Chadwick VS. Dose-related effects of chenodeoxycholic acid in the rabbit colon. Dig Dis Sci. 1980;25(6):433-438.

17. Alrefai WA, Saksena S, Tyagi S, Gill RK, Ramaswamy K, Dudeja PK. Taurodeoxycholate modulates apical $\mathrm{Cl}-\mathrm{OH}$ exchang activity in Caco2 cells. Dig Dis Sci. 2007;52(5):1270-1278. doi:10.1007/s10620 $-006-9090-8$

18. Ridlon JM, Kang DJ, Hylemon PB. Bile salt biotransformations by human intestinal bacteria. J Lipid Res. 2006;47(2):241-259. doi: 10.1194/jlr.R500013-JLR200

19. Hylemon PB, Harder J. Biotransformation of monoterpenes, bile acids, and other isoprenoids in anaerobic ecosystems. FEMS Microbiol Rev. 1998;22(5):475-488. doi:10.1111/j.1574-6976.1998.tb00382.x

20. Raufman JP, Zimniak P, Bartoszko-Malik A. Lithocholyltaurine interacts with cholinergic receptors on dispersed chief cells from guinea pig stomach. Am J Physiol. 1998;274(6 Pt 1):G997-1000. doi:10.1152 /ajpgi.1998.274.6.G997

21. Kirwan WO, Smith AN, Mitchell WD, Falconer JD, Eastwood MA. Bile acids and colonic motility in the rabbit and the human. Gut. 1975; 16(11):894-902. doi:10.1136/gut.16.11.894

22. Snape WJ Jr, Shiff S, Cohen S. Effect of deoxycholic acid on colonic motility in the rabbit. Am J Physiol. 1980;238(4):G321-325. doi: 10.1152/ajpgi.1980.238.4.G321

23. Edwards CA, Brown S, Baxter AJ, Bannister JJ, Read NW. Effect of bile acid on anorectal function in man. Gut. 1989;30(3):383-386. doi: 10.1136/gut.30.3.383

24. Bampton PA, Dinning PG, Kennedy ML, Lubowski DZ, Cook IJ. The proximal colonic motor response to rectal mechanical and chemical stimulation. Am J Physiol Gastrointest Liver Physiol. 2002; 282(3):G443-449. doi:10.1152/ajpgi.00194.2001

25. Odunsi S, Camilleri M, Bushiglio I, et al. Effects of chenodeoxycholic acid on gastrointestinal and colonic transit and bowel function in health volunteers. Gastroenterology. 2009;136(Suppl 1):A531. doi: 10.1016/j.cgh.2009.10.02

26. Shiff SJ, Soloway RD, Snape WJ Jr. Mechanism of deoxycholic acid stimulation of the rabbit colon. J Clin Invest. 1982;69(4):985-992. doi:10.1172/jci110538

27. Fernandez-Banares F, Esteve M, Salas A, et al. Systematic evaluation of the causes of chronic watery diarrhea with functional characteristics. Am J Gastroenterol. 2007;102(11):2520-2528. doi: 10.1111/j.1572-0241.2007.01438.x

28. Sadik R, Abrahamsson H, Ung KA, Stotzer PO. Accelerated regional bowel transit and overweight shown in idiopathic bile acid malabsorption. Am J Gastroenterol. 2004;99(4):711-718. doi:10.1111/j.1572 -0241.2004.04139.x

29. Pattni S, Walters JR. Recent advances in the understanding of bile acid malabsorption. Br Med Bull. 2009;92:79-93. doi:10.1093/bmb /ldp032

30. Camilleri M. Bile acid diarrhea: Prevalence, pathogenesis, and therapy. Gut Liver. 2015;9(3):332-339. doi:10.5009/gnl14397

31. Vijayvargiya $P$, Busciglio I, Burton $D$, et al. Bile acid deficiency in subgroup of patients with irritable bowel syndrome with constipation based on biomarkers in serum and fecal samples. Clin Gastroenterol Hepatol. 2018;16(4):522-552. doi:10.1016/j.cgh.2017.06.039

32. Shin A, Camilleri M, Vijayvargiya $P$, et al. Bowel functions, fecal unconjugated primary and secondary bile acids, and colonic transit in patients with irritable bowel syndrome. Clin Gastroenterol Hepatol. 2013;11(10):1270-1275.e1. doi:10.1016/j.cgh.2013.04.020
33. Rao AS, Wong BS, Camilleri M, et al. Chenodeoxycholate in females with irritable bowel syndrome-constipation: A pharmacodynamics and pharmacogenetic analysis. Gastroenterology. 2010;139(5):1549-1558,1558.e1. doi:10.1053/j.gastro.2010.07.052

34. Abrahamsson $H$, Ostlund-Lindqvist AM, Nilsson R, Simrén M, Gillberg PG. Altered bile acid metabolism in patients with constipation-predominant irritable bowel syndrome and functional constipation. Scand J Gastroenterol. 2008;43(12):1483-1488. doi:10.1080 /00365520802321212

35. Marcus SN, Heaton KW. Intestinal transit, deoxycholic acid and the cholesterol saturation of bile: Three inter-related factors. Gut. 1986;27(5):550-558. doi:10.1136/gut.27.5.550

36. Hofmann AF. The continuing importance of bile acids in liver and intestinal disease. Arch Intern Med. 1999;159(22):2647-2658.

37. Hofmann AF, Loening-Baucke V, Lavine JE, et al. Altered bile acid metabolism in childhood functional constipation: Inactivation of secretory bile acids by sulfation in a subset of patients. J Pediatr Gastroenterol Nutr. 2008;47(5):598-606. doi:10.1097/MPG .0b013e31816920a6

38. Chey WD, Camilleri M, Chang L, et al. A randomized placebo-controlled phase Ilb trial of a3309, a bile acid transporter inhibitor, for chronic idiopathic constipation. Am J Gastroenterol. 2011;106(10): 1803-1812. doi:10.1038/ajg.2011

39. Acosta A, Camilleri M. Elobixibat and its potential role in chronic idiopathic constipation. Ther Adv Gastroenterol. 2014;7(4):167-175. doi:10.1177/1756283X14528269

40. Nakajima A, Seki M, Taniguchi S. Determining an optimal clinical dose of elobixibat, a novel inhibitor of the ileal bile acid transporter, in Japanese patients with chronic constipation: A phase II, multicenter, double-blind, placebo-controlled randomized clinical trial. J Gastroenterol. 2018;53(4):525-534. doi:10.1007/s00535-017-1383-5 